
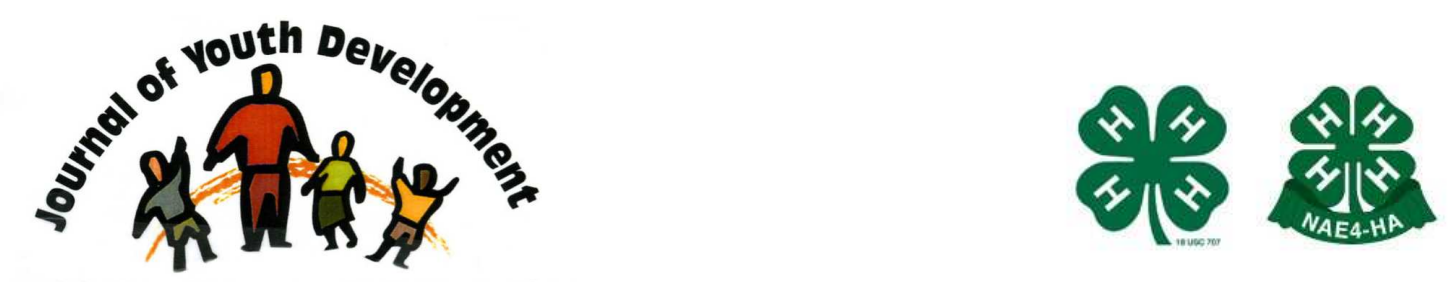

Bridging Research \& Practice

\title{
Using Poverty Simulation for College Students: A Mixed-Methods Evaluation
}

\author{
Maureen Todd \\ Research and Extension \\ University of Nebraska-Lincoln \\ Lincoln, NE \\ maureen.todd@huskers.unl.edu \\ Maria Rosario T. de Guzman \\ Research and Extension \\ University of Nebraska-Lincoln \\ Lincoln, NE \\ mguzman2@unl.edu \\ Xiaoyun Zhang \\ Research and Extension \\ University of Nebraska-Lincoln \\ Lincoln, NE \\ pkuzxy@yahoo.com
}




\title{
JOURNAL OF YOUTH DEVELOPMENT \\ bridging research and practice

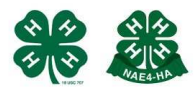

Bridging Research \& Practice

Volume 6, Number 2, Summer 2011

Article 110602PA001

\section{Using Poverty Simulation for College Students: A Mixed-Methods Evaluation}

\author{
Maureen Todd, Maria Rosario T. de Guzman and Xiaoyun Zhang \\ University of Nebraska-Lincoln
}

\begin{abstract}
This paper speaks to the potential for simulation and experience-based educational programs in delivering changes in knowledge, attitudes and behaviors, as well as the utility of mixedmethods approaches to program evaluation. The authors discuss a mixed-methods study which evaluates the impact of a poverty simulation program on college students at three Midwestern universities. Findings suggest multiple benefits of the experience, including changes in attitudes and beliefs about how serious the experience of poverty can be, an understanding that poverty is complex and can be caused by multiple factors, and a decrease in their biases and stereotypes about people in poverty. Qualitative findings corroborate these data.
\end{abstract}

\section{Introduction}

Community Action Poverty Simulation ${ }^{\odot}$ (CAPS) is a unique tool that agencies use to educate participants about the day-to-day realities of people living with limited resources. Simulation activities, because of their experiential and hands-on nature, can be a very effective and powerful way for participants to gain a host of skills and insights, particularly for children and adolescents (Adams, 1973; Lehtola, 2007). This simulation takes approximately three hours and participants role-play the lives of low-income families. The task is for participants to 'survive' financially - navigating institutions, acquiring basic necessities, and tackling occasional hurdles that many families in poverty face (e.g., child becomes ill). While this simulation has been used in many settings, the systematic evaluation of its effectiveness among college students through multiple sources of data is lacking.

The current evaluation study was conducted with college students who were in CAPS as part of a general education class. During the simulation, each participant was given an identity (e.g., Joan, mother) and assigned to one of up to 26 limited-resource households. Each person within that household had to work together to obtain and allocate the necessary resources to survive 
each 15 minute interval which represented one week in their lives. Each family was given a certain amount of resources (e.g., cash, bus passes) with some families having more than others. Participants also interacted with community services, agencies and businesses from which they could either gain more resources (e.g., borrow money from the bank, obtain food stamps, sell to the pawnshop) and/or purchase and pay for needs (e.g., grocery store, utility company). One volunteer periodically and randomly distributed cards that represented unforeseen circumstances, for instances, the 'sick child' card meant that one of the adults in the family/group had to sit out a portion of the interval (representing having to stay home with the sick child) to care for the child. This resulted in being unable to get a full week's pay, having less time to buy groceries and pay utilities, and fulfill other necessities. A family that received the card indicating that their car was broken had to give out a portion of their money to purchase bus passes. At the end of each interval, each family was asked to examine how well they did in covering their basic needs. Upon the end of four 15-minute cycles, participants completed the post-test evaluation and joined a de-briefing and sharing of their experiences and thoughts.

The reported mixed-methods study is an independent evaluation of the program and assesses its effectiveness in bringing about belief and attitude change among college students. Because many college students show a low level of financial literacy and have an increasing amount of debt (Norvilities, Osberg, Young, Merwin, Roehling \& Kamas, 2006), they are a priority population for this type of program. Financial decisions and good financial management are crucial for youth to be effective contributors to the well-being of the community and national economy (Spencer, Petty, Stimpson, Dees \& Riley, 2003). Furthermore, the students in this study were enrolled in programs in which they were training to work with families and youth in the community and as such it was essential that they learned about the experience of poverty. A mixed-methods approach was utilized in order to gather multiple sources of data and to establish a comprehensive evaluation of the program (Creswell \& Plano Clark, 2007).

\section{Methods}

Participants of this study were 509 college students from three Midwest universities. Preliminary analyses indicated no systematic differences in the demographic and survey data across schools, thus, data were collapsed across universities. Majority described themselves as Caucasian (92\%), 2.6\% as African American, 2.5\% as Hispanic, and 2\% as Asian. Participants had a mean age of 21.82 years $(S D=8.99)$. Students participated in the poverty simulation program as part of a class activity in a general education course.

The Poverty Simulation program package includes a 16-item survey that is used to assess participants' attitudes and beliefs regarding poverty. This measure was given immediately prior to and after the activity. The post-test survey also included two qualitative questions that asked what insights they had gained and what actions they planned to take as a result of their experience.

\section{Results}

\section{Quantitative data}

Factor analysis with varimax rotation was conducted to examine the properties of the 16-item survey. Analyses yielded four factors explaining $48.89 \%$ of the variance. Repeated measures ANOVA were then conducted to compare pre- and post-test scores on those factors, with 
results summarized in Table 1 . Results show that students gained attitude change in three of the four sub-scales.

Table 1

Descriptive statistics and results of within-groups comparisons

\begin{tabular}{|c|c|c|c|c|}
\hline & $\begin{array}{c}\text { Percent of variance } \\
\text { accounted for }\end{array}$ & $\begin{array}{c}\text { Pre-test } \\
\text { Means(SD) }\end{array}$ & $\begin{array}{c}\text { Post-test } \\
\text { Means(SD) }\end{array}$ & $\begin{array}{c}\text { Results of repeated measures } \\
\text { ANOVA }\end{array}$ \\
\hline $\begin{array}{c}\text { Severity of poverty: } \\
\text { Poverty is not a serious } \\
\text { problem and poor } \\
\text { people get enough help. }\end{array}$ & $15.16 \%$ & $2.32(.53)$ & $2.11(.65)$ & $f(1,569)=85.32 * * *, M S e=(.16)$ \\
\hline $\begin{array}{c}\text { Self responsibility. Poverty } \\
\text { is simply the fault of } \\
\text { poor people. }\end{array}$ & $13.80 \%$ & $2.76(.64)$ & $2.54(.70)$ & $f(1,569)=95.98^{* * *}, M S e=(.16)$ \\
\hline $\begin{array}{c}\text { Bad habits. Poor people } \\
\text { have bad habits }\end{array}$ & $10.84 \%$ & $2.18(.78)$ & $1.91(.79)$ & $f(1,569)=16.70^{* * *, M S e}=(.27)$ \\
\hline $\begin{array}{c}\text { The toll poverty takes. } \\
\text { Poverty takes an } \\
\text { emotional toll }\end{array}$ & $9.09 \%$ & $3.44(.67)$ & $3.38(.82)$ & $\begin{array}{l}f(1,569)=2.10, M S e=(.25)(\mathrm{no} \\
\text { significant change })\end{array}$ \\
\hline
\end{tabular}

*** $\mathrm{p}<.001$ Note: participants did not score significantly differently between pre- and post-tests for the final scale

\section{Qualitative data}

Qualitative responses were coded using a typological approach which entailed collapsing similar responses and then further combining categories with similar ideas. This allows researchers to reflect on the ways people discuss particular topics, seek relationship in their responses, and to develop the scope of their experience (Morse \& Richards, 2002). Two independent coders (graduate students) undertook the analysis and compared their findings to provide data validity and triangulation. In order to check for reliability, a second pair of coders (two undergraduates) independently coded the data following the coding protocol which resulted in agreement in findings. A fifth and final independent researcher compared results from the first and second set of codes, and then to the entire corpus of responses. Results were as follows (sample responses in parentheses):

Question 1: What did you learn from this experience?

- $\quad$ Living in poverty is difficult

("Being poor is difficult and it is even harder to get out of poverty!")

- $\quad$ Living in poverty is emotionally hard and stressful

("I'm just shocked at the stress of it all. I have a headache, and I was not even the one budgeting money.")

- Increased empathy and understanding for the less privileged.

("I have learned that poor people do work hard and that they often are in a cycle that is difficult to change. They are not poor because of their faults.")

- There is help for people in poverty but not enough

("You really have to take advantage of the resources that you do have"; "There should be more programs to help people.") 
Question 2: Has this workshop encouraged you to take action on anything or make changes in your life?

- Motivated to act to avoid ending up in poverty by studying harder, finding work, budgeting better

("It has made me want to get a good education.")

- Help others who are in need

("I want to give to charity now whenever I can afford to ... some kind of help for the homeless.")

- Be more thankful for what one has

("Be appreciative because people get by with much less.")

- Want to help, just don't know how yet

("I would love to help people more but I feel like I can't help. I am just out of school - I have massive debt.")

\section{Conclusions and Implications}

While this evaluation study utilized a short-term pre- and post-test design, results suggest multiple benefits of the poverty simulation experience for college students. Quantitative findings indicate that participants changed their attitudes and beliefs about how serious the experience of poverty can be, how poverty is not purely a result of people's own doing (e.g., being lazy), and decreased their biases against people in poverty, specifically that people in need exhibit many bad habits. Qualitative findings corroborate the quantitative data and suggest that participants displayed increased knowledge about the challenges that low-income families face, and that they had an increased amount of empathy for those in need. Participants also indicated that they were motivated to change their behaviors, for instance, expressing a desire to act in ways that would help them avoid poverty in the future, as well as to find ways to help those in need.

Findings support scholars' assertions regarding the potential for simulation and other experience-based educational programs in delivering changes in knowledge, attitudes and behaviors. In this poverty simulation program, participants experience to some degree, the difficulties that low-income people typically undergo, and are tasked with trying to solve issues similar to what people in need have to deal with on a daily basis. These experiences appear to be effective in reaching the goals of the program.

Simulations have been shown to be effective in a variety of areas, including training adolescents to deal with issues related to suicide (Kalafat, \& Gagliano, 1996), practicing decision-making in situations surrounding teen pregnancy (Condon, Corkindale, Russell, \& Quinlivan, 2006) as well as in learning about conflict resolutions and negotiation (Kifer, Levis, Green, \& Phillips, 1974). Simulation exercises, wherein participants are actively engaged in problem solving and in practicing other skills, can be an effective way for youth to gain practical information in a hands-on manner and can be incorporated in many programs (Lehtola, 2007). By employing exercises wherein youth can practice skills in the context of real life scenarios, learning can become more meaningful.

Finally, findings highlight the potential for the mixed-methods approach for program evaluation. While the quantitative data showed numeric and measurable changes in scores on specific 
outcomes, the qualitative data provide a rich illustration of the experiences, thoughts, and feelings of students undergoing the simulation. Together, these methods complement each other and provide a more comprehensive picture of program impact.

\section{Acknowledgement:}

The authors would like to thank the UNL Extension Educators who conducted the simulation - Marilyn Fox, Carla Mahar, Mary Nelson, and Ruth Vonderohe; as well as the students and volunteers who participated in the exercise.

\section{References}

Adams, D.M. (1973). Simulation Games: An Approach to Learning. Worthington, Ohio: Charles A. Jones Publishing.

Condon, J.T., Corkindale, C.J., Russell, A., \& Quinlivan, J.A. (2006). Processes and factors underlying adolescent males' attitudes and decision-making in relation to an unplanned pregnancy, Journal of Youth and Adolescence, 35 (3), 447-458.

Creswell, J.W., \& Plano Clark, V.L. (2007). Designing and conducting mixed methods research. Thousand Oaks, CA: Sage.

Kalafat, J., \& Gagliano, C. (1996). The use of simulations to assess the impact of an adolescent suicide response curriculum. Suicide and Life-Threatening Behaviors, 26 (4), 359-364.

Kifer, R.E., Lewis, M.A., Green, D.R., \& Phillips, E.L. (1974). Training predelinquent youths and their parents to negotiate conflict situations. Journal of Applied Behavior Analysis, 7 (3), 357364.

Lehtola, C.J. (2007). Developing and Using Table-Top Simulations as a Teaching Tool. Journal of Extension [On-line], 45(4). Article: 4TOT4. Available at:

http://www.joe.org/joe/2007august/tt4.php

Missouri Association for Community Action. (2010). Community Action Poverty Simulation. Jefferson City, MO: MACA. Available at: http://www.communitycation.org

Morse, J.M., \& Richards, L. (2002). Read Me First for a User's Guide to Qualitative Methods. Thousand Oaks, CA, Sage.

Norvilities, J.M., Osberg, T.M., Young, P., Merwin, M.M., Roehling, P.V., \& Kamas, M.M. (2006). Personality factors, money attitudes, financial knowledge and credit card debt in college students. Journal of Applied Social Psychology, 36, 1395-1413.

Spencer, M., Petty, B., Stimpson, J., Dees, L., \& Riley, L. (2003). "Welcome to the Real World" positively affects youth financial management skills, knowledge, and attitudes. Journal of Extension [On-line], 41. Available at: http://www.joe.org/joe/2003april/tt3.php

(C) Copyright of Journal of Youth Development Bridging Research and Practice. Content may not be copied or emailed to multiple sites or posted to a listserv without copyright holder's express written permission. However, users may print, download or email articles for individual use. 